\title{
From the Editor
}

\section{Things That Go 'Bump' in the House Douglas McCormick}

Editorial Director, BioTechniques

The most unsettling thing about the House Energy and Commerce Committee's hearings on "Germs, Viruses, and Secrets: The Silent Proliferation of Bio-Laboratories in the United States" is the title.

.... In the night, imagining some fear,

How easy is a bush supposed a bear!

A Midsummer Night's Dream, Act v. Sc. 1.

ust as this issue went to press, the U.S. House Energy and Commerce Committee's subcommittee on oversight and investigations opened hearings on "Germs, Viruses, and Secrets: The Silent Proliferation of Bio-Laboratories in the United States."

The topic-in fact, a discussion of the expanding number and activity of biosafety level 3 and 4 laboratories, especially those engaged in research on agents of biological warfare and terrorism-deserves serious discussion, as the record of the past couple of months certainly makes that clear: Texas A\&M (College Station, TX) shut down biodefense research and the school's vice president of research resigned after it was revealed that the university had failed to notify the Centers for Disease Control and Prevention that one worker had contracted brucellosis and three others had had contact with Coxiella burnetti, the cause of $Q$ fever. More recently, British investigators traced an outbreak of hoof-and-mouth disease to a leaky drain shared by the UK Institute for Animal Health and vaccine-maker Merial Animal Health.

\section{Upping the Dread Ante}

Two days before the hearings, the Associate Press turned up the paranoia thermostat by reporting that "American laboratories handling the world's deadliest germs and toxins have experienced more than 100 accidents and missing shipments since 2003 , and the number is increasing as more labs do the work." The article did concede that "no one died, and regulators said the public was never at risk," but had clearly settled into viewing-with-alarm mode, chronicling animal-bite, needle-stick, and lost-animal incidents "involving anthrax, bird flu virus, monkeypox, and plague-causing bacteria."

Investigation showed, though, that exposed workers were quarantined and treated, and that "lost" animals had been sterilized with their bedding or eaten by cage mates. Accidents, in short, did happen, but established procedures contained the problem.

This is not to minimize the potential danger or disparage the need for caution, training, and disclosure. But we have formulated our procedures in the certain knowledge that animals will bite, researchers will jab themselves with needles and alter their topography with scalpels and razor blades, that animals will die and, yes, that mice will occasionally eat other mice.

\section{The Peril of "Bio-Laboratories"}

In the end, the general tone of the hearing testimony* was sober and knowledgeable, despite occasional attempts from the rostrum to paint researchers as unconcerned about safety and uninformed about their own activities. (It sometimes seemed, though, that questioners and witnesses were not absolutely sure what kinds of labs they were meant to worry about: biodefense labs, labs registered with the Select Agents Program [a joint undertaking of the Centers for Disease Control and Prevention and the Department of Agriculture], all high-containment labs, or all biology labs.)

What unsettled us most, though, were the echoes of menace in the hearing title-which represents, after all, the founding assumptions of the conveners.

"Germs, viruses, and secrets" has a dire ring. One wonders what level of scientific understanding prompted the distinction between germs and viruses. And what are those "bio-laboratories," out there, spawning in the dark? We can't recall having encountered the term before, outside of a trademark or two. "We don't know what 'bio-laboratories' are," the title seems to say, "but we're pretty sure they're not good, especially if they're proliferating... and doing it silently, the sneaky devils. We're going to have to keep an eye on them, whatever they are."

*Printed testimony and an archived webcast of the hearing are online at the Energy and Commerce Committee web site, energycommerce.house.gov/cmte_mtgs/110-oi-hrg.100407.BSL.shtml. 